of properly designed research projects based on a coherent logical framework. It is because of the general excellence of the book in this respect that one is surprised to come across the following statement (Chapter 5, p. 154): "It is clear that there is no difference between dysthymies, hysterics and normals in sleeping pulse, the group means being virtually identical. This seems to be an important finding, since it indicates that only during the waking state do individuals differ in their level of autonomic arousal, the differences disappearing during sleep". Now the groups referred to number only 10 in each of the neurotic groups and 20 in the normal group. Thus the conclusion that there is in general no difference between the groups so far as sleeping pulse rate, and therefore levels of autonomic arousal during sleep, is clearly unwarranted. The null hypothesis cannot be proved. The authors should have ascertained whether the differences of the waking group were significantly greater than the differences of the sleeping group; this was not done.

In general, this book is a valuable contribution to the application of experimental method in the study of personality.

R. F. Garside

\section{ASPECTS OF PHARMACOLOGY}

Annual Review of Pharmacology

Vol. 3. Edited by Windsor C. Cutting, in association with Robert H. Dreisbach and Henry W. Elliott. Pp. vi +486. (Palo Alto, Calif.: Annual Reviews, Inc., 1963.) 8.50 dollars.

$\mathrm{V}$ OLUME 3 of Annual Review of Pharmacology, the youngest member of the Annual Reviews Inc. group of publications, continues in the traditions they have established.

The first article is Sir Henry Dale's account of his 'accidental' entry into pharmacology 60 years ago. It provides a striking contrast to the conditions of presentday students in Britain, on whom early specialization is forced by rigid curricula and the demands of those who administer their grants. Pharmacologists of about the same age as, or younger than, me must be a little puzzled by Sir Henry's account of his entry into pharmacology: from our point of view he did not so much enter pharma. cology as play an instrumental part in establishing it.

Most of the remaining eighteen reviews in this volume are on various aspects of pharmacology, but the especially significant fact is that many of the reviews are orientated towards a discipline other than pharmacology.

Biochemical orientation is seen in the review on "Enzymes as Primary Targets of Drugs" by Zeller and Fouts, which stresses 'enzymological aspects'. It is unfortunately limited to the enzymes cholinesterase and monoamine oxidase. Perhaps this is due to influences derived from Sir Henry Dale, and his influence is seen again in the review by Volle on the "Pharmacology of the Autonomic Nervous System". The orientation in Volle's review is to the borderland between physiology and pharmacology where the study of drugs and the study of physiological mechanisms becomo one. The review by Shideman and Mannering on "Metabolic Fate" also contains a biochemical theme.

Toxicology is well represented, with one review on radioactive metals, another on organic compounds, and a third with the intriguing title of "The Pharmacology and Toxicology of the Environment", which deals with the effects of contaminants of food, water and air.

As might be expected, the physiological orientation occurs most often; drugs considered in relation to their effects on the cardio-vascular, endocrine and nervous systems, or to some sub-section of these systems. The short review by Weeks on "Physiological Techniques in Pharmacology" discusses novel and original methods for measuring many of the physiological functions which are of particular interest to pharmacologists.

The final review is again the "Review of Reviews" by Chauncey D. Leake. This contribution also appeared in the first two volumes of Annual Review of Pharmacology and now seems to be an established feature; it is succinct and useful. I hope it will continue in future volumes together with the other custom, if that is the way to describe an event occurring three times, of devoting the first article to the reminiscences of an eminent pharmacologist.

M. J. RAND

\section{PORTRAIT OF A LIBRARIAN}

\section{Edward Edwards 1812-1886}

Portrait of a Librarian. By W. A. Munford. Pp. $240+9$ plates. (London: The Library Association, 1963.) $48 s$.

$\mathrm{W}$ HEN Greenwood published his life of 'T. E. Edwards more than sixty years ago, Edwards had been dead for only sixteen years and Greenwood perforce omitted much of interest regarding this controversial pioneer of public libraries. These shortcomings Dr. Munford, who acknowledges his debt to Greenwood, both in respect of the earlier biography and also of the letters, papers and manuscripts which Greenwood collected and which are now deposited with the Manchester Central Library in the Greenwood Library for Librarians, seeks to rectify. He has, however, given us a scholar's book copiously referenced which the student of the early development of the public library system in Great Britain will value. This and the high price, however, may limit the effectiveness of the book in bringing home to some of the many thousands of users of public libraries to-day the immense debt they owe to Edwards and his Parliamentary associate, William Ewart, to whose life Dr. Munford devoted an earlier book.

This is unfortunate, for the career and achievements of this self-educated son of a bricklayer tiler, who, at the age of twenty-one, so impressed a Select Committee of the House of Commons by a pamphlet he submitted commenting on their Minutes of Evidence that, when later in the same year this Select Committee on the British Museum was reappointed, Edwards was summoned to give evidence, deserve to be widely known. Dr. Munford has, in fact, given a balanced and readable portrait of Edwards; his lack of self-discipline, which made it impossible for him to control the length of his books or to regulate his private finance; his impatience, as well as his vision; his quickness to take offence; his lack of tact, as well as his many lovable and human traits, are displayed as clearly as the vicissitudes of his career, the meanness with which he was treated as the first librarian of Manchester, the wide range of his reading, and the soundness of much of his thought on the practice of librarianship.

Above all, Dr. Munford indicates the soundness of Edwards's claim to be one of the pioneers of the public library in Britain, and while it is improbable that, however reasonably and generously he had been treated by the Manchester Public Free Libraries Committee, or had he not fallen out with Panizzi at the British Museum, his career would have been other than stormy, it is at least possible that in happier circumstances Edwards's constructive contribution to the development of the public library might have been even greater. Certainly his energies would scarcely have been so widely dispersed in voluminous writings, of which comparatively few, except perhaps Memoirs of Libraries, Libraries and Founders of Libraries, or Lives of the Founders of the British Museum are of any value to-day. As it is, Dr. Munford does justice to the real achievements of a self-made, self-opinionated pioneer whose real worth few of his contemporaries appreciated, partly no doubt because he was an uneasy colleague, and partly because much of his thought was ahead of his time.
R. BRIGHTMAN 